\title{
IMPACT OF FEEDING SYSTEMS ON PHYSIOLOGICAL, REPRODUCTIVE AND PRODUCTIVE PERFORMANCE OF SHAMI GOATS DURING DIFFERENT PHYSIOLOGICAL STAGES
}

\author{
M.T. Badawy and K.M. Youssef \\ Animal and Poultry Division, Desert Research Center, Cairo, Egypt
}

\section{SUMMARY}

The study aimed to investigate the effect of feeding systems that prevails in North Sinai on Shami goats productivity. Reproductive performance, blood metabolites, colostrum and milk composition as well as growth performance and carcass traits of their weaned kids were discussed. Three groups (20 each) of Shami goats (3-3.5 yrs old $42.5 \pm 1.16 \mathrm{Kg}$ body weight), were assigned to simulate one of the following feeding systems; S1 composed of four harvested annual plants as a sole diet without any supplements, S2 supplemented with yellow corn (500g/head/day) while, the third group (S3) was offered berseem (Trifolium alexandrinum) hay ad libitum plus concentrates feed mixture (CFM).

The treatments started at the breeding season ( $1^{\text {st }}$ June, 2004) up to weaning of kids (90 days) and continued on 10 weaned male kids from each respective group through fattening trail (120 day) and thereafter five kids per group were slaughtered; daily gain, carcass weight, grade and dressing percentage were also tested.

Results showed that feeding system was of pronounced effect on crude protein intake (g/head/day) and gross energy (MJ / $\mathrm{kg} D M)$ from such simulated rations which was reflected in their milk yield and composition as well as productive efficiency of their kids (average daily gain and carcass traits) compared to the other two systems. During the experimental period, average DMI/ head/day was 1450.3, 1920 and $2375 \mathrm{~g} / \mathrm{head} /$ day, respectively, being higher in S3 and S2 compared to S1. Likewise, milk yield was found to be $0.95,1.400$ and $1.800 \mathrm{~kg} / \mathrm{head} /$ day as well as pre weaning daily gain of 119.4, 180 and $198.9 \mathrm{~g}$., respectively.

In does, supplementary feeding (S2 group) had improved conception rate, kidding rate and fecundity by 10.0, 5.5 and $20.4 \%$, respectively compared to S1 group. In the meantime, average daily gain (135 g/head/ day), carcass score (2.3) and dressing percentage $(50.0 \%)$ were improved $(P<0.05)$ in $S 2$ compared to S1 group $(97.5$ $\mathrm{g} / \mathrm{head} /$ day, 1.4 and $47.2 \%$, respectively).

On the other hand, blood metabolites were fluctuated $(P<0.05)$ among feeding systems during different physiological stages, although values were within the normal range reported in the literature. Time of parturition was accompanied with the lowest values of most blood parameters. Urea increased on the day of parturition and almost stabilized thereafter. Creatinine value was the highest just after kidding (1.04 g/dl). Activities of AST and ALT did not show regular trend.

It could be concluded that extensive feeding, particularly the natural ranges, seemed to cover the maintenance requirements from crude protein and still suffering a shortage in energy. The urgent need to supplementary feeding is still required

Issued by The Egyptian Society of Animal Production 
especially during hyper metabolic activity within the physiological stresses of pregnancy and lactation. The relatively poor performance obtained of Shami goats under extensive system might limit its spread allover North Sinai Governorate due to their higher requirements compared to the black Bedouin ones. Blood parameters during the gestation period were fluctuated among the feeding systems reflecting the physiological mechanisms under different feeding systems.

Keywords: Shami goats, feeding, blood constituents, colostrum, milk, daily gain, carcass grade, reproduction

\section{INTRODUCTION}

Small ruminants are the most dominant livestock in North Sinai region of Egypt. They play an important role in the social life and economic status of Bedouins. The feeding of those animals is based mainly on the native natural vegetation which varies greatly in plant species, varieties, productivity, chemical composition and nutritive value according to forage locations and the stage of growth due to many environmental factors. Most of goat production systems have been practiced in the region based mainly on grazing natural rangelands with or without feed supplements depending on the situation of the rangelands. Some goat flocks are fed indoors with concentrate plus good quality roughages.

Damascus (Shami) goats, in particular, are characterized by their high milk production and faster growth rate in addition to their large size relative to Baladi goats (Zarkawi and Soukouti, 2004) and were planed to be distributed through the MERC project in North Sinai to improve productivity of local breeds. Their adaptability and potentialities that fit with the prevailing arid conditions of the region concerning pregnancy, parturition and early lactation periods, as metabolic stresses, as well as growing performance of their kids have not been adequately investigated.

Inadequate feed intake during pregnancy causes a reduction in birth weight, mammary gland development and milk production and subsequent high mortality (Mellor and Murray, 1985). There is also a high demand on protein for udder growth and colostrum production in the last 2 weeks of pregnancy for multiparous does, Voluntary feed intake declines despite the higher demand for nutrients (Bell, 1995). Moreover, eighty percent of the fetal growth during late pregnancy resulted in a significant increase in nutrient requirements (Bell, 1995 and Dawson et al., 1999).

Feeding pregnant Shami does (during physiological stresses, gestation and lactation as large body size animals and subsequently higher maintenance requirements to provide adequate energy and protein for embryonic and fetal growth, maintenance of the animal's physiological needs, mammary gland growth and development, colostrum and milk yield) seemed to be a great challenge to spread such breed in desert areas whenever, grazing is the only feed source.

This study aimed to investigate the impact of different feeding systems on the changes in some blood metabolites parameters during pregnancy and early lactation stages and, the colostrum and milk constituents of the Damascus (Shami) goats. Also, growth performance and carcass quality of their kids were evaluated. 


\section{MATERIALS AND METHODS}

Location

The present study was carried out in north eastern region (Al-Arish Valley - Zarea Elkhair) of North Sinai Governorate, Egypt on small holder Bedouins. This research was a part of the project supported under Grant No., M18-001, Bureau and entitled "Middle East Regional Cooperation" (MERC), program for Economic, Growth, Agriculture and Trade, U.S. Agency for International Development.

Management and feeding

In this area, four plant species (most dominant) naturally grown during the wet season (winter and spring) namely; Broumus uniloides, Cutandia memphitica, Medicago coronata and Paronychia argentea. These plants are palatable and sometimes overgrazed by sheep and goats. Plants were randomly collected and clipped using 10 quadrates ( $2 \mathrm{~m}$ x $2 \mathrm{~m}$ each). Fresh yield from each plant species was weighed immediately after collection and its density was calculated and recorded. Composite samples of each plant were dried, ground and kept for chemical analysis.

The annual plant species were harvested and composed to be offered daily, as a sole diet, ad libitum for two groups of animals with and without feed supplements (yellow corn at the rate of $500 \mathrm{~g} / \mathrm{head} /$ day) to simulate the extensive and semiintensive feeding systems. In addition, traditional diets of berseem (Trifolium alexandrinum) hay for ad libitum feeding plus concentrate (CFM) feed mixture (36\% yellow corn, $12 \%$ cotton seed meal, $5 \%$ soybean meal, $42 \%$ wheat bran, $3 \%$ molasses, $1 \%$ limestone, $0.5 \%$ sodium chloride and $0.5 \%$ mineral mixture) offered twice daily at the rate of $1.5 \mathrm{~kg}$ were offered to another group to simulate the intensive feeding system. Representative samples from each feed ingredients were analyzed for proximate chemical analyses according to AOAC (1996). Fresh water was available freely for all groups once daily.

Experimental design

Three groups (20 each) of Shami does, 3-3.5 years old, $42.5 \pm 1.16 \mathrm{Kg}$ live body weight and similar body condition score, were kept indoors in wire-fenced pens and assigned to one of the following feeding systems; a composed of four plant species without supplementation (S1), supplemented with $500 \mathrm{~g}$ yellow corn/head/day (S2) and, berseem hay ad libitum plus concentrate feed mixture (S3). Live body weights of does are shown in Table 3, Does were kept with their born kids together under shelters.

The experiment started during the breeding season $\left(1^{\text {st }}\right.$ June, 2004). Does were mated by five fertile bucks rotated among doe groups for 40 days (equal two estrous cycles) and their briskets were painted with greasy colour to detect does in estrus. Reproductive data in terms of conception rate (CR), kidding rate (KR), fecundity (FD) was determined.

After weaning at 90 days old, 10 male kids of each respective group were used in a fattening trail (120 day) on the same previous rations. Then, five kids of each group were slaughtered. Feed intake (FI), average daily gain (ADG), carcass weight (CW), grade and dressing percentage (DP) were recorded.

Blood, colostrum and milk analyses

Blood samples were collected through vein puncture into tubes contained EDTA, as anti-coagulant, before feed and water offer. Samples were taken just before mating and at biweekly intervals during pregnancy, just after parturition and weekly 
thereafter up to 3 months of lactation period. Packed cell volume (PCV \%) and hemoglobin $(\mathrm{Hb}, \mathrm{g} / \mathrm{dl})$ concentration were determined in whole blood samples. While, the remainder was centrifuged at $3000 \mathrm{rpm}$ for 20 minutes to obtain clear plasma that stored at $-20^{\circ} \mathrm{C}$ till further analysis.

Blood metabolites in terms of plasma total protein (TP, g/dl), albumin (Alb, g/dl), blood urea nitrogen $(\mathrm{BUN}, \mathrm{mg} / \mathrm{l})$, creatinine $(\mathrm{Cr}, \mathrm{mg} / \mathrm{l})$, alanine aminotranaminase (AST, U/L) and aspartate aminotranaminase (ALT, U/l) were determined using test kits supplied by the Egyptian-American company according to their manufacture procedures.

Colostrum samples were obtained by hand milking of each doe immediately after parturition (day 1 ) and thereafter at $2^{\text {nd }}$ and $3^{\text {rd }}$ day then at weekly interval up to 12 week lactation period then frozen at $-20^{\circ} \mathrm{C}$ till chemical analysis for total solids (TS), fat $(\mathrm{F})$, solids not fat (SNF), protein (P) and lactose (Lact.) using Milk scan (N.Foss electric, Denmark). The energy output in colostrums and milk were calculated using the percentages of lactose, protein and fat, and the factors of 16.54, 24.52 and 38.12 $\mathrm{Kcal} / \mathrm{Kg}$, respectively according to McDonald et al. (1995).

Statistical analysis of data was executed using the general linear model (GLM) of SAS (1998) for repeated measurements. The differences among means were tested using Duncan test (1955).

\section{RESULTS AND DISCUSSION \\ 1. Feed intake}

Dry matter (DM) yield and proximate composition of the offered four dominant annual plants are presented in Table (1). The total DM yield of the whole annual range plants was estimated as $954 \pm 11.9 \mathrm{~kg} /$ feddan. The greatest yield was recorded for Medicago coronata followed by Bromus unilioides and Paronychia argentea. They attained the highest density / unit area being 32.7, 25.3 and $23 \%$, respectively. Such forages should be protected from overgrazing as promising forages in this area. The crude protein content ranged from $10.9 \%$ in Paronychia argentea to $13.1 \%$ in (Medicago coronata) with an overall mean of $11.7 \%$. This content was mostly above the recommended levels by at least $8.9 \%$ in plant material recommended by the United States National Academy of Science (1975). These results suggest that such forages, during the wet season, can safely cover and maintain the requirements of goats.

Crude protein intake (g/head/day) as well as total energy intake (MJ/head/day) varied among the different feeding systems being higher in S3 (375.9 and 42.01 followed by S2 (211.6 and 34.60) compared to the extensive group (S1, 169.7 and 25.90), respectively (Table 2). During the experimental period, average daily DM intake increased with the advancement of pregnancy and lactation period being higher for S3 group (2291 and $2526 \mathrm{~g} /$ head/day) followed by S2 (1774 and $2076 \mathrm{~g} /$ head/day) compared to S1 (1298 and $697 \mathrm{~g} / \mathrm{head} /$ day) during late gestation and early lactation periods, respectively with an overall mean of $1450.3,1920$ and $2375 \mathrm{~g} / \mathrm{head} /$ day representing 3.4, 4.5 and $5.6 \%$ of their initial live body weight.

The plant species, dominant in the pasture in North Sinai seemed to cover goats' maintenance requirements only, but animals still suffering from feed shortage (energy) especially during hyper metabolic activity (pregnancy and lactation periods) 
where voluntary feed intake declined despite the higher demand for nutrients (Bell, 1995).

Table 1. Mean values of dry matter yield (DM) and chemical composition of the both dominant annual plants and feed ingredients (on DM basis)

\begin{tabular}{|c|c|c|c|c|c|c|c|c|}
\hline \multirow[b]{2}{*}{ Plant Species } & \multicolumn{2}{|c|}{ DM yield } & \multicolumn{6}{|c|}{ Chemical composition } \\
\hline & $\mathbf{K g}$ & $\%$ & DM & Ash & $\mathbf{C P}$ & CF & $\mathbf{E E}$ & NFE \\
\hline Bromus unilioides & 242 & 25.3 & 34.4 & 5.5 & 11.3 & 34.4 & 2.1 & 46.7 \\
\hline Cutandia memphitica & 165 & 19.0 & 27.6 & 7.3 & 11.6 & 28.7 & 1.5 & 44.9 \\
\hline Medicago coronata & 311 & 32.7 & 22.9 & 11.5 & 13.1 & 27.6 & 2.1 & 45.7 \\
\hline Paronychia argentea & 236 & 23.0 & 35.1 & 6.8 & 10.9 & 38.0 & 2.4 & 41.9 \\
\hline Overall mean & 954 & 100 & 30.0 & 7.8 & 11.7 & 32.2 & 2.0 & 44.8 \\
\hline \multicolumn{9}{|l|}{ Ingredients and rations } \\
\hline & & DM & $\mathrm{OM}$ & Ash & $\mathrm{CP}$ & $\mathrm{CF}$ & $\mathrm{EE}$ & NFE \\
\hline Berseem hay & & 88.7 & 87.7 & 12.3 & 15.2 & 25.6 & 2.1 & 44.9 \\
\hline $\begin{array}{l}\text { Concentrate feed mixture } \\
\text { (CFM) }\end{array}$ & & 90.6 & 92.6 & 7.4 & 16.3 & 9.9 & 3.4 & 63.0 \\
\hline Yellow corn & & 91.5 & 88.5 & 2.6 & 8.8 & 2.4 & 3.3 & 82.9 \\
\hline \multicolumn{9}{|c|}{ Calculated chemical composition of tested rations } \\
\hline $\mathrm{S} 1$ ration & & 100 & 92.4 & 7.6 & 11.7 & 32.2 & 2.0 & 46.5 \\
\hline $\mathrm{S} 2$ ration & & 100 & 93.6 & 6.4 & 11.0 & 25.2 & 2.3 & 55.1 \\
\hline $\mathrm{S} 3$ ration & & 100 & 90.5 & 9.5 & 15.8 & 16.7 & 2.8 & 55.2 \\
\hline
\end{tabular}

DM; dry matter. CP; crude protein. CF; crude fiber. EE, ether extract. NFE, nitrogen free extract. S1 ration: composed of 4 harvested plants S2 ration: the same S1 ration plus $500 \mathrm{~g} / \mathrm{head} /$ day of yellow corn. S3 ration: berseem hay plus concentrate feed mixture

Table 2. Dry matter (DMI) and calculated nutrients intake of different feeding systems

\begin{tabular}{lccc}
\hline \multirow{2}{*}{ ITEMS } & \multicolumn{3}{c}{ Feeding systems } \\
\cline { 2 - 4 } & & S2 & S3 \\
\hline Dry matter intake (DMI, g/head/day) & & 1470 & 1025 \\
From plants (roughage) & 1450.3 & 450 & 1350 \\
From concentrate & ---- & 1920 & 2375 \\
Total DMI, g/head/day & 1450.3 & 44.96 & 55.88 \\
Total DMI, g/kg body weight & 34.37 & & \\
Calculated nutrients intake (g/head/day) & 1796.7 & 2150.1 \\
Organic matter (OM) & 1340.1 & 123.4 & 226.0 \\
Ash & 110.2 & 211.6 & 375.91 \\
Crude Protein (CP) & 169.7 & 484.1 & 396.1 \\
Crude fiber (CF) & 467.0 & 44.3 & 67.4 \\
Ether extract (EE) & 29.0 & 1056.7 & 1310.7 \\
Nitrogen free extract (NFE) & 674.4 & 18.02 & 17.69 \\
Gross energy (MJ/kg DM) & 17.86 & 34.60 & 42.01 \\
Total energy intake & 25.90 & & \\
(MJ/head/day) & & & \\
\hline Gross energy concentration (MJ/kg DM), calculated according to MAFF (1975) using the \\
following equation: GE=0.0226CP+0.0407 EE+ 0.0192 CF+ $0.0177 \mathrm{NFE}$
\end{tabular}




\section{Reproductive performance}

During pregnancy, does gained weight being 5.3, 6.2 and $8.1 \mathrm{~kg}$ for S1, S2 and S3 groups, respectively (Table 3), indicating the better ability of S1 and S2 groups to consume such plant species while, the highest increases was found in S3 group. However, differences were not significant. It is clear that there was a trend in body gain increase as feed quality and quantity improved.

The effect of feeding system was clear $(\mathrm{P}<0.01)$ on $\mathrm{CR}, \mathrm{KR}, \mathrm{FD}$ as well as kid's birth weight $(\mathrm{P}<0.05)$. The extensive feeding group ( $\mathrm{S} 1)$ showed the lowest values compared with either S2 or S3 (On the other hand, supplementary feeding for S2 group resulted in improving CR, KR and fecundity by $10,5.5$ and $20.4 \%$, respectively compared to $\mathrm{S} 1$ group that fed only on the harvested plant species (Table $3)$.

This finding suggests the urgent needs for supplementary feeding since these regions are exposed to long drought seasons for long periods which affected animal's productivity and survival ability.

Table 3. Reproductive performance of doe groups under different feeding systems

\begin{tabular}{lccc}
\hline \multicolumn{1}{c}{ Items } & \multicolumn{3}{c}{ Feeding system } \\
\cline { 2 - 4 } & S1 & S2 & S3 \\
\hline No. of does joined & 20 & 20 & 20 \\
Initial live body weight & $42.2 \pm 2.01$ & $42.7 \pm 1.9$ & $42.5 \pm 2.16$ \\
Live body weight just before & $47.5 \pm 1.56$ & $48.9 \pm 1.95$ & $50.6 \pm 2.10$ \\
kidding & & & \\
Weight gain during pregnancy & $5.3 \pm 0.68$ & $6.2 \pm 0.55$ & $8.1 \pm 0.56$ \\
No of does conceived & 17 & 19 & 19 \\
Conception rate (\%) & $85^{\mathrm{a}}$ & $95^{\mathrm{b}}$ & $95^{\mathrm{b}}$ \\
No. of kids born & 19 & 25 & 30 \\
Kidding rate (\%) & $89.5^{\mathrm{a}}$ & $95^{\mathrm{b}}$ & $95^{\mathrm{b}}$ \\
Fecundity (kids & $1.11^{\mathrm{a}}$ & $1.31^{\mathrm{b}}$ & $1.57^{\mathrm{c}}$ \\
kidded) born/doe & \multicolumn{3}{c}{} \\
Average birth weight (kg) & $1.75 \pm 0.59^{\mathrm{a}}$ & $2.3 \pm 0.88^{\mathrm{b}}$ & $2.6 \pm 0.75^{\mathrm{b}}$ \\
\hline a,b and c superscript means are differed significantly at $\mathrm{P}<0.05$
\end{tabular}

\section{Colostrum constituents and milk yield}

Composition and calorific value of colostrum at $1^{\text {st }}, 2^{\text {nd }}, 3^{\text {rd }}, 7^{\text {th }}$ and $28^{\text {th }}$ day as related to different dietary feeding systems are presented in Table 4. Results demonstrated that colostrum of the intensive feeding group (S3) was rich in TS, SNF, $\mathrm{TP}(\mathrm{P}<0.05)$ and gross energy than those of either $\mathrm{S} 1$ (being higher by 13, 14.4, 34.4 and $14 \%$, respectively) or S2 (being higher by $13.4,16.5,19$ and $9.3 \%$, respectively) with the lowest value in lactose content. Oyeniyi and Hunter (1978) and Jacobson and McGillard (1984) stated that the lower concentrations of lactose in colostrum are considered an advantage because lactose can induce the young to scour (diarrhea) with subsequent death or unthriftness which support our results.

The increase in calorific value of colostrum produced in S3 could be attributed to the increase in fat content $(8.06 \%)$, which is considered a biological advantage. Furthermore, D'Oherty and Crosby (1997) showed a positive relationship between 
CP supplementation pre-lambing and colostrum production and IgG transfer to the newly born lambs. Also, Ocak et al. (2005) found that ewes fed on $115 \%$ of their maintenance requirements of $\mathrm{CP}$ (soybean meal) had greater concentrations $(\mathrm{P}<0.01)$ of $\mathrm{IgG}$ in colostrum than ewes fed $85 \% \mathrm{CP}$.

Table 4. Colostrum and transitional milk constituents of Shami goats under different dietary feeding systems

\begin{tabular}{|c|c|c|c|}
\hline \multirow[b]{2}{*}{ Constituents $\%$} & \multicolumn{3}{|c|}{ Feeding systems } \\
\hline & S1 & S2 & S3 \\
\hline \multicolumn{4}{|l|}{ Colostrum $^{1}$} \\
\hline Total solids & $17.86 \pm 0.69^{\mathrm{a}}$ & $17.80 \pm 0.63^{\mathrm{a}}$ & $20.18 \pm 0.69^{b}$ \\
\hline Fat & $7.28 \pm 0.57^{\mathrm{a}}$ & $7.38 \pm 0.52^{\mathrm{a}}$ & $8.06 \pm 0.57^{\mathrm{a}}$ \\
\hline Solid not fat & $10.59 \pm 0.44^{\mathrm{a}}$ & $10.40 \pm 0.40^{\mathrm{a}}$ & $12.12 \pm 0.44^{\mathrm{b}}$ \\
\hline Protein & $5.88 \pm 0.44^{\mathrm{a}}$ & $6.64 \pm 0.40^{\mathrm{a}}$ & $7.90 \pm 0.44^{\mathrm{b}}$ \\
\hline Lactose & $3.85 \pm 0.12^{\mathrm{a}}$ & $3.76 \pm 0.11^{\mathrm{a}}$ & $3.16 \pm 0.12^{b}$ \\
\hline Gross energy, $\mathrm{kcal} / \mathrm{kg}$ & $1160.1 \pm 55^{\mathrm{a}}$ & $1210.1 \pm 50^{\mathrm{a}}$ & $1322.1 \pm 55^{\mathrm{a}}$ \\
\hline \multicolumn{4}{|l|}{ Transitional milk $^{2}$} \\
\hline Milk yield (kg/head/day) ${ }^{1}$ & $0.95 \pm 0.54^{\mathrm{a}}$ & $1.4 \pm 0.54^{b}$ & $1.8 \pm 0.54^{\mathrm{c}}$ \\
\hline Total solids $\%$ & $11.94 \pm 0.60^{\mathrm{a}}$ & $11.72 \pm 0.53^{\mathrm{a}}$ & $12.78 \pm 0.60^{\mathrm{a}}$ \\
\hline Fat $\%$ & $3.28 \pm 0.57^{\mathrm{a}}$ & $3.38 \pm 0.52^{\mathrm{a}}$ & $3.73 \pm 0.57^{\mathrm{a}}$ \\
\hline $\begin{array}{l}\text { Fat produced daily } \\
\text { (g/head/day) }\end{array}$ & $31.2 \pm 0.12$ & $47.3 \pm 0.16$ & $67.1 \pm 0.22$ \\
\hline Solid not fat $\%$ & $8.66 \pm 0.34^{\mathrm{a}}$ & $8.34 \pm 0.28^{\mathrm{a}}$ & $9.05 \pm 0.34^{\mathrm{a}}$ \\
\hline Protein \% & $3.77 \pm 0.16^{\mathrm{a}}$ & $3.96 \pm 0.14^{\mathrm{a}}$ & $4.03 \pm 0.14^{\mathrm{a}}$ \\
\hline $\begin{array}{l}\text { Protein produced daily } \\
(\mathrm{g} / \text { head })\end{array}$ & $35.8 \pm 0.12$ & $55.44 \pm 0.12$ & $72.5 \pm 0.12$ \\
\hline Lactose $\%$ & $4.60 \pm 0.18^{\mathrm{a}}$ & $3.97 \pm 0.16^{\mathrm{a}}$ & $4.16 \pm 0.18^{\mathrm{ab}}$ \\
\hline Gross energy, $\mathrm{kcal} / \mathrm{kg}$ & $701.6 \pm 47^{\mathrm{a}}$ & $696.9 \pm 45^{\mathrm{a}}$ & $740.4 \pm 45^{\mathrm{a}}$ \\
\hline $\begin{array}{l}\text { Energy produced } \\
\text { (kcal/head/day)* }\end{array}$ & 666.52 & 975.66 & 1332.72 \\
\hline
\end{tabular}

Means with different letters in the same row are differed significantly at $(\mathrm{P}<0.05) .1$; average of $1^{\text {st }}$ and $2^{\text {nd }}$ days post partum. 2; average of $1^{\text {st }}, 2^{\text {nd }}, 3^{\text {rd }}$ and $4^{\text {th }}$ weeks post partum. 1 , milk yield was calculated over 90 day lactation period. * Energy produced $(\mathrm{kcal} / \mathrm{head} / \mathrm{day})=\mathrm{milk}$ yield $\mathrm{x}$ gross energy

Effect of feeding system on milk yield was also observed. Supplementary feeding in $\mathrm{S} 2$ had improved milk yield $(\mathrm{P}<0.05)$ by $47.4 \%(1400 \mathrm{vs} .950 \mathrm{~g} / \mathrm{head} / \mathrm{day})$ compared to S1 while S3 was the highest (1800 g/head/day).

The results indicated that the $1^{\text {st }}$ day colostrum had the highest calorific value as well as concentration of all constituents except lactose being the lowest (Table 5). The sharp changes in colostrum constituents and its calorific value from parturition up to the $2^{\text {nd }}$ day colostrum might be attributed to its storage inside the mammary gland since the beginning of its biosynthesis is in prepartum. The present results were in accordance with those of Nowakowski, et al. (1992), Csapo et al. (1998) and Abdel-Moneim (1999). They reported that levels of most components in colostrum decreased $(\mathrm{P}<0.01)$ during $1^{\text {st }} 24$ hrs postpartum. 
Further decreases in milk chemical composition occurred in its gross energy with the advancement of days postpartum with a descending pattern, being 17.7, 11.7, 7.6 and $4.5 \%$ for $1^{\text {st }}$ to $2^{\text {nd }}, 2^{\text {nd }}$ to $3^{\text {rd }}, 3^{\text {rd }}$ to $4^{\text {th }}$ and $4^{\text {th }}$ to $7^{\text {th }}$ days postpartum, respectively. While, fat content decreased with ascending order being 4.9, 8.2, 9.6 and $4.5 \%$ at the same previous periods, respectively. The lowest concentration of lactose was in the $1^{\text {st }}$ day's colostrum just after lambing, but it increased gradually in an ascending order thereafter by days postpartum (Table 5).

Table 5. Changes in milk composition of Shami goats as affected by days postpartum

\begin{tabular}{lcrrrr}
\hline \multirow{2}{*}{\begin{tabular}{c} 
Constituents \\
\cline { 2 - 5 }
\end{tabular}} & \multicolumn{5}{c}{ Days postpartum } \\
\cline { 2 - 5 } & $\mathbf{1}^{\text {st }}$ & $\mathbf{2}^{\text {nd }}$ & $\mathbf{3}^{\text {rd }}$ & $7^{\text {th }}$ & $\mathbf{2 8}^{\text {th }}$ \\
\hline Total solids & $23.11 \pm 0.7^{\mathrm{a}}$ & $18.90 \pm 0.8^{\mathrm{b}}$ & $16.69 \pm 0.8^{\mathrm{c}}$ & $15.53 \pm 0.8^{\mathrm{c}}$ & $15.05 \pm 0.8^{\mathrm{c}}$ \\
Fat & $8.37 \pm 0.6^{\mathrm{a}}$ & $7.16 \pm 0.6^{\mathrm{a}}$ & $5.31 \pm 0.6^{\mathrm{a}}$ & $4.11 \pm 0.6^{\mathrm{a}}$ & $3.14 \pm 0.6^{\mathrm{a}}$ \\
Solids not fat & $14.73 \pm 0.5^{\mathrm{a}}$ & $10.96 \pm 0.5^{\mathrm{b}}$ & $9.39 \pm 0.5^{\mathrm{c}}$ & $8.93 \pm 0.5^{\mathrm{c}}$ & $8.99 \pm 0.5^{\mathrm{c}}$ \\
Protein & $10.66 \pm 0.5^{\mathrm{a}}$ & $6.26 \pm 0.5^{\mathrm{b}}$ & $4.60 \pm 0.5^{\mathrm{c}}$ & $4.31 \pm 0.5^{\mathrm{c}}$ & $3.89 \pm 0.4^{\mathrm{c}}$ \\
Lactose & $2.88 \pm 0.2^{\mathrm{c}}$ & $3.66 \pm 0.2^{\mathrm{b}}$ & $4.00 \pm 0.2^{\mathrm{b}}$ & $3.90 \pm 0.2^{\mathrm{b}}$ & $4.49 \pm 0.2^{\mathrm{a}}$ \\
Kcal/ kg & $1501 \pm 62^{\mathrm{a}}$ & $1163.9 \pm 62^{\mathrm{b}}$ & $911.5 \pm 62^{\mathrm{bc}}$ & $781.2 \pm 62^{\mathrm{c}}$ & $679.8 \pm 55^{\mathrm{c}}$ \\
\hline
\end{tabular}

Means with different superscripts within the same row are significantly different $(\mathrm{P}<0.05)$

Variations in colostrums quality (daily protein, fat and energy produced) and total milk yield was positively reflected on the productive performance of their kids. Results of the present study indicated that feeding pregnant Shami does, during gestation and lactation periods, under extensive feeding system considered one of the main challenges in order to provide adequate energy and protein to support embryonic and fetal growth, mammary gland growth, colostrum and milk yield in addition to maintain the animal's physiology needs. Eighty percent of the fetal growth during late pregnancy resulted in a significant increase in nutrient requirements (Bell, 1995; Dawson et al., 1999). There is also a large increase in the net protein requirements for udder growth and colostrum production in the last 2 weeks of pregnancy for multiparous does.

Inadequate feed intake during pregnancy has contributed to reduction in birth weight, mammary gland development and milk production and subsequent high mortality (Mellor and Murray, 1985) which confirmed the results of the extensive feeding system (S1). On the other hand, colostrum production is extremely important, as it is the first nutrient for the newborn kids that provide fuel for heat production, growth factors and antibodies to give immunological protection against infections (Pakkanen and Aalto, 1997). In the present study, clostrum production with its gross energy did not differ significantly among the three feeding systems.

\section{Kid performance}

The effect of nutrition on body weight and condition was clearly visible on the animals of both S2 and S3 groups compared to S1 group (Table 6). The higher birth weight observed in both S2 and S3 compared to S1 might be related to milk yield. Pre-weaning average daily gain was parallel to milk yield estimated, kids of S1 had scored the lowest value (119.4 g/head/day) and kids of S3 recorded the highest one 
(198.9 g/head/day) while supplementary feeding $(\mathrm{S} 2)$ had improved $(\mathrm{P}<0.05)$ preweaning daily gain (180.0 vs. $119.4 \mathrm{~g} /$ head/day) compared to S1 group.

Excess CP diet could have increased the proportion of propionate in relation to other volatile fatty acids and hence increased the glucose entry rate in pregnant ewes (Hafez and Maareck 2002). Pregnant does utilize propionate as the main source of glucose. On the other hand, the higher level in pregnant does fed excess CP might increased fetal growth, resulting in a higher birth weight (Kleemann et al., 1993). Accordingly, kids of S1 were the lowest in all productive traits (Table 6), compared to the other two groups reflecting on their average daily gain as well as body condition score and carcass traits. So, S3 and S2 kids group recorded a higher mean of warm carcass weight (21.7 and $17.4 \mathrm{~kg})$ and carcass grade (3.3 and 2.3) as a result of more fat deposits compared to S1 group (11.5 and grade 1.4). Also, it has been found that protein nutrition in late pregnancy can influence colostrum yield by affecting the net flux of amino acids to and from the carcass tissues (McNeill et al., 1997) that can ultimately influence mammary gland and uterine tissue growth (Dawson et al., 1999). The present results reflect the need to supplementary feeding for fattening kids on the pasture plants in order to improve their productive performance and subsequently, increasing the owner income of such small holders where kids or lambs represent the main source of income. Feed conversion efficiency ( $\mathrm{kg} \mathrm{DMI} / \mathrm{kg}$ gain) was favour to S1 (7.4) compared to the other two groups (S2, 8.8 and S3, $9.0 \mathrm{~kg}$ ) but supplementary feeding was of great interest, it seemed to be more economic practical under extensive feeding condition which reflected positively on Bedouins income.

Table 6. Kids performance $(M \pm S E)$ as affected by different feeding systems

\begin{tabular}{|c|c|c|c|}
\hline \multirow{2}{*}{ Parameters } & \multicolumn{3}{|c|}{ Feeding system } \\
\hline & S1 & $\mathbf{S 2}$ & $\mathbf{S 3}$ \\
\hline Average birth weight $(\mathrm{kg})$ & $1.75 \pm 0.59^{\mathrm{a}}$ & $2.3 \pm 0.88^{b}$ & $2.6 \pm 0.75^{b}$ \\
\hline Weaning weight (kg) & $12.5 \pm 1.2^{\mathrm{a}}$ & $18.5 \pm 0.69^{b}$ & $20.5 \pm 0.86^{\mathrm{b}}$ \\
\hline Pre-weaning daily gain & $119.4 \pm 12.56^{\mathrm{a}}$ & $180 \pm 16.25^{\mathrm{b}}$ & $198.9 \pm 21.54^{\mathrm{b}}$ \\
\hline \multicolumn{4}{|c|}{ Dry matter intake (g/head/day } \\
\hline From plants & 720 & 920 & 845 \\
\hline From concentrates & ---- & 270 & 750 \\
\hline TDMI & 720 & 1190 & 1595 \\
\hline Final body weight $(\mathrm{kg})$ & $24.2 \pm 1.7^{\mathrm{a}}$ & $34.7 \pm 1.3^{b}$ & $41.7 \pm 1.5^{b}$ \\
\hline Body weight gain $(\mathrm{Kg})$ & 11.7 & 16.2 & 21.2 \\
\hline Average daily gain (g/h/day) & $97.5 \pm 5.67^{\mathrm{a}}$ & $135.0 \pm 12.54^{\mathrm{b}}$ & $176.7 \pm 9.15^{\mathrm{c}}$ \\
\hline Feed conversion efficiency* & 7.4 & 8.8 & 9.0 \\
\hline Warm carcass weight $(\mathrm{kg})$ & $11.5 \pm 0.9^{\mathrm{a}}$ & $17.4 \pm 0.55^{\mathrm{b}}$ & $21.7 \pm 0.65^{\mathrm{b}}$ \\
\hline Carcass grade & $1.4 \pm 0.4^{\mathrm{a}}$ & $2.3 \pm 0.4^{\mathrm{b}}$ & $3.3 \pm 0.4^{\mathrm{b}}$ \\
\hline Dressing \% & 47.2 & 50.0 & 52.1 \\
\hline
\end{tabular}

S1; Extensive managed. S2; Semi-extensive managed. S3; Intensive managed. Means with different superscripts within the same row are significantly different $(\mathrm{P}<0.05)$. *; feed conversion efficiency ( $\mathrm{kg} \mathrm{DMI} / \mathrm{kg}$ gain). 


\section{Blood parameters}

Regarding feeding systems, blood parameter concentrations in the present study were within the normal physiological ranges reported by Reece (1991); Frandson and Spurgeon (1992) for healthy sheep and goats. Both $\mathrm{Hb}(\mathrm{g} / \mathrm{dl})$ and PCV \% values were nearly similar in both S2 (14.07 g/dl and 39.7) and S3 (14.07 g/dl and 40.6) and insignificantly higher than those of S1 $(13.4 \mathrm{~g} / \mathrm{dl}$ and $34.8 \%)$ group, respectively (Table 7). These results are in agreement with those of Rekwot et al. (1999) who reported that $\mathrm{Hb}$ concentration was significantly higher due to a high protein diet (14. $5 \%$ ) than those of low dietary protein $(8.5 \%)$.

Plasma TP tended to increase $(\mathrm{P}<0.05)$ in both S3 $(7.1 \mathrm{~g} / \mathrm{dl})$ and S2 $(7.4 \mathrm{~g} / \mathrm{dl})$ groups compared with $\mathrm{S} 1$ group $(5.95 \mathrm{~g} / \mathrm{dl})$ while plasma Alb concentrations were almost similar for the three feeding systems. Results were partially in concurrent with results of Rekwot et al. (1999). They pointed out that higher plasma TP values coincided with the high level of dietary protein. Likewise, globulin concentration tended to increase $(\mathrm{P}<0.05)$ associated with the increase in $\mathrm{CP}$ level of the rations resulted in a significant effect on $\mathrm{A} / \mathrm{G}$ ratio. In contrast, Hatfield et al. (1998) reported a tendency of increasing $(\mathrm{P}<0.01)$ serum proteins with the decrease of dietary protein from $18 \%$ to $10 \%$ in lamb's rations.

Table 7. Blood biochemical parameters of Shami goats as affected by different dietary feeding systems

\begin{tabular}{lccc}
\hline \multicolumn{1}{c}{ Parameters } & \multicolumn{3}{c}{ Feeding systems } \\
\cline { 2 - 4 } & S1 & S2 & S3 \\
\hline Packed cell volume (PCV \%) & $34.8 \pm 1.51^{\mathrm{a}}$ & $39.7 \pm 1.37^{\mathrm{a}}$ & $40.6 \pm 1.51^{\mathrm{a}}$ \\
Hemoglobin conc. (Hb,g/dl) & $13.4 \pm 0.44^{\mathrm{a}}$ & $14.07 \pm 0.44^{\mathrm{a}}$ & $14.07 \pm 0.44^{\mathrm{a}}$ \\
Total proteins (TP, g/dl) & $5.95 \pm 0.26^{\mathrm{a}}$ & $7.4 \pm 0.26^{\mathrm{b}}$ & $7.1 \pm 0.26^{\mathrm{b}}$ \\
Albumin (Alb, g/dl) & $2.75 \pm 0.07^{\mathrm{a}}$ & $2.7 \pm 0.07^{\mathrm{a}}$ & $2.75 \pm 0.07^{\mathrm{a}}$ \\
Globulin (Glb, g/dl) & $3.20 \pm 0.20^{\mathrm{a}}$ & $4.7 \pm 0.20^{\mathrm{b}}$ & $4.35 \pm 0.20^{\mathrm{b}}$ \\
Albumin/globulin ratio & $0.86 \pm 0.08^{\mathrm{a}}$ & $0.57 \pm 0.08^{\mathrm{b}}$ & $0.63 \pm 0.08^{\mathrm{b}}$ \\
Glucose (Glu, g/dl) & $86.6 \pm 0.55^{\mathrm{a}}$ & $88.9 \pm 0.54^{\mathrm{a}}$ & $91.0 \pm 0.56^{\mathrm{a}}$ \\
Urea (Ur, mg/dl) & $43.9 \pm 2.33^{\mathrm{a}}$ & $43.4 \pm 2.33^{\mathrm{a}}$ & $43.6 \pm 2.33^{\mathrm{a}}$ \\
Creatinine (Cr, mg/dl) & $0.61 \pm 0.05^{\mathrm{a}}$ & $0.92 \pm 0.06^{\mathrm{a}}$ & $0.77 \pm 0.06^{\mathrm{a}}$ \\
ALT (U/L) & $17.2 \pm 1.66^{\mathrm{a}}$ & $19.7 \pm 1.66^{\mathrm{a}}$ & $21.3 \pm 1.66^{\mathrm{a}}$ \\
AST (U/L) & $85.71 \pm 3.3^{\mathrm{a}}$ & $99.4 \pm 3.6^{\mathrm{a}}$ & $76.9 \pm 3.6^{\mathrm{a}}$ \\
\hline Means with different superscripts are significantly different (P<0.05). &
\end{tabular}

Value of BUN was insignificantly affected by feeding system. This contrasted with those results of Roeder et al. (2000) who found that BUN and Alb were greater $(\mathrm{P}<0.05)$ in ewes fed the normal $\mathrm{CP}$ diets compared to their counterparts fed $65 \% \mathrm{CP}$ of NRC (1986). Meanwhile, Cr concentration was lower $(\mathrm{P}<0.05)$ in $\mathrm{S} 1$ group than the other two groups. Liver and kidneys of pregnant does were experiencing a state of hyper-function as reported by El-Sherif and Assad (2001). They reported that the higher need for energy and protein catabolism led to an increase in urea and creatinine levels to an extent above the ability of kidneys to eliminate excess amounts 
from plasma, these effects were not confirmed in the present study indicating that feeding system was of insignificant effects on kidney function.

On the other hand, stress, irrespective of the cause, predisposes to gluconeogensis, with an associated rise in circulatory transaminases (Iriadam, 2007). Plasma AST and ALT activity tended to increase as dietary CP level increased, although the differences were not significant. The increase in ALT and AST might not be attributed to any pathological causes. Otherwise, this increase might indicate impairment in some muscle and liver cells due to rapid gluconeogenesis associated with pregnancy. Activity of AST was proved to increase under the effect of glucocorticoids which are released more during pregnancy (Bell et al., 1961).

Changes in blood constituents as affected by physiological status are presented in Table 8. Time of parturition was accompanied with the lowest values of $\mathrm{Hb}, \mathrm{PCV} \%$, $\mathrm{TP}$ and $\mathrm{G}$ and highest concentrations of plasma Alb and $\mathrm{A} / \mathrm{G}$ ratio. The present results agree well with those reported by Bhat (1999) who found that $\mathrm{Hb}$ values were higher during the prepartium period and decreased after calving, but in contrary, he reported an opposite trend for plasma TP protein. Purohit et al. (1999) reported that values of $\mathrm{Hb}$ and serum $\mathrm{TP}$ at the end of the $3^{\text {rd }}$ and $4^{\text {th }}$ month of pregnancy in ewes were lower $(\mathrm{P}<0.01)$ than those of non-pregnant ewes.

Plasma TP of lactating does declined to reach a level equal to the pre mating ones (Table 8) which is in agreement with TaKarkheade et al (1999) and El-Sherif and Assad, (2001). This decline might be due to a sharp decrease in Glb that might be used for milk protein (casein) and antibodies formation. In the present study, Alb was maintained with slow rate of decline resulted in higher $(\mathrm{P}<0.01) \mathrm{A} / \mathrm{G}$ ratio. This trend of change in plasma TP might represents an adaptive response to the higher need of water mobilization by blood to mammary glands for milk production.

In agreement with the present results, Parveen and Ahuja (1999) found that up to 60 to $40 \mathrm{hrs}$ prepartum, there was an increase in plasma protein which then declined up to $20 \mathrm{hrs}$ postpartum. They suggested an accumulation of protein in the plasma of buffaloes in late gestation and then the secretion to the mammary gland initiated 20 to $10 \mathrm{hrs}$ prepartum which continued until $24 \mathrm{hrs}$ postpartum.

The increased $(\mathrm{P}<0.05)$ Glu level during pregnancy might reflect the hyper metabolic state that animal suffered during pregnancy stress and the higher need for Glu, the output of adrenocorticotrophic hormone, glucocorticoids and adrenaline is increased for breakdown of liver glycogen (Bell et al., 1961). Lioyd (1974) and Hil et al. (1984) reported that the concentration of adrenal corticoids rises during pregnancy and act especially in mobilizing amino acids from body protein, which is associated with an increased rate of hepatic deamination and conversion of certain of the resultant ketoacids to glucose (Allen, 1977). 
Table 8. Changes in blood constituents of Shami does in relation to the physiological status

\begin{tabular}{lcccc}
\multicolumn{1}{c}{ Parameters } & \multicolumn{4}{c}{ Physiological Status } \\
\cline { 2 - 5 } & Pre-mating & Pregnancy & Parturition & Lactation \\
\hline Packed cell volume & $32.6 \pm 1.46^{\mathrm{a}}$ & $50.2 \pm 1.46^{\mathrm{a}}$ & $33.9 \pm 1.46^{\mathrm{b}}$ & $34.6 \pm 1.46^{\mathrm{b}}$ \\
(PCV\%) & & & \\
Hemoglobin conc. & $13.5 \pm 0.42$ & $14.3 \pm 0.42^{\mathrm{a}}$ & $13.3 \pm 0.42^{\mathrm{a}}$ & $14.9 \pm 0.42^{\mathrm{a}}$ \\
(Hb,g/dl) & $6.5 \pm 0.26$ & $7.0 \pm 0.25^{\mathrm{ab}}$ & $7.3 \pm 0.25^{\mathrm{b}}$ & $6.1 \pm 0.26^{\mathrm{a}}$ \\
Total proteins (TP, g/dl) & $2.85 \pm 0.07$ & $2.4 \pm 0.07^{\mathrm{a}}$ & $2.98 \pm 0.07^{\mathrm{b}}$ & $2.85 \pm 0.07^{\mathrm{b}}$ \\
Albumin (A, g/dl) & $3.33 \pm 0.28$ & $4.6 \pm 0.28^{\mathrm{a}}$ & $4.34 \pm 0.28^{\mathrm{b}}$ & $3.33 \pm 0.28^{\mathrm{a}}$ \\
Globulin (G, g/dl) & $0.86 \pm 0.08$ & $0.52 \pm 0.08^{\mathrm{a}}$ & $0.89 \pm 0.08^{\mathrm{b}}$ & $0.66 \pm 0.08^{\mathrm{c}}$ \\
Albumin/globulin ratio & $55.6 \pm 0.55$ & $92.5 \pm 0.55^{\mathrm{a}}$ & $78.7 \pm 0.55^{\mathrm{b}}$ & $68.6 \pm 0.55^{\mathrm{c}}$ \\
Glucose & $33.8 \pm 2.33$ & $35.9 \pm 2.33^{\mathrm{a}}$ & $46.2 \pm 2.33^{\mathrm{b}}$ & $48.8 \pm 2.33^{\mathrm{b}}$ \\
Urea (Ur, mg/dl) & $0.43 \pm 0.06$ & $0.63 \pm 0.06^{\mathrm{a}}$ & $1.04 \pm 0.06^{\mathrm{b}}$ & $0.63 \pm 0.06^{\mathrm{a}}$ \\
Creatinine (Cr, mg/dl) & $103.9 \pm 3.52$ & $70.02 \pm 3.52^{\mathrm{a}}$ & $87.8 \pm 3.52^{\mathrm{b}}$ & $103.9 \pm 3.52^{\mathrm{c}}$ \\
ALT (U/L) & $22.4 \pm 1.66$ & $19.5 \pm 1.66^{\mathrm{ab}}$ & $16.7 \pm 1.66^{\mathrm{b}}$ & $22.4 \pm 1.66^{\mathrm{a}}$ \\
AST (U/L) & & & \\
\hline
\end{tabular}

Means with different superscripts are significantly different $(\mathrm{P}<0.05)$.

After parturition, a marked decrease in Glu was in accordance with those of Bedo et al. (1997). The present results reflected the heavy demand for glucose during lactation. Regnault et al. (2004), on lactating ewes, demonstrated that many tissues became less sensitive to insulin stimulation during lactation, which supports milk production by increasing the amount of glucose and possibly amino acids available for the mammary gland.

\section{CONCLUSION}

It could be concluded that plant species dominant, during wet season, in the pasture seemed to cover the maintenance requirements of Shami goats and should be protected from overgrazing and spread over pastures with some justifications. Extensive feeding, particularly on natural ranges seemed to be practical and more economic when fattening male kids and improved income might be realized when applied supplementary feeding. On the other hand, animals could sustain their physiological mechanisms without adverse effects under extensive feeding system. This study warrants further research regarding the investigation of nutrition programs in terms of energy requirements to let this breed to express its genetic potentiality before Introduction to arid and semi arid areas in North Sinai Governorate.

\section{ACKNOWLEDGEMENT}

This research was supported by Grant No., M18-001, Middle East Regional Cooperation (MERC) program, Bureau for Economic Growth, Agriculture and Trade, U.S. Agency for International Development. Great thanks are due to professor El-Shaer, H. M., the principle investigator, for the continuous encouragement, saving all facilities and reading manuscript. This support is greatly appreciated. 


\section{REFERENCES}

Abdel-Moneim, A.Y., 1999. Colostrum and milk composition of Rahmani sheep and Zaraibi goats. J. Agric. Sci., Mansoura Univ., 24: 2177.

Allen, R.S., 1977. Protein metabolism. In: Swenson, M.J. (Ed.), Duke's Physiology of Domestic Animals, $9^{\text {th }}$ Edition. Cornell University Press, Ithaca, $346 \mathrm{pp}$.

AOAC, 1996. Official Methods of Analysis (16 ${ }^{\text {th }}$ Ed.). Associatioin of Official Analytical Chemists. Washington, DC, USA.

Bell, A.W., 1995. Regulation of organic nutrient metabolism during transition from late pregnancy to early lactation. J.Anim. Sci., 73: 2804.

Bell, G.H., J.H. Davson and H. Scarborough, 1961. Textbook of Physiology and Biochemistry, $5^{\text {th }}$ Edition. Neil \& Co. Ltd., Edinburgh, UK, p. 291.

Bedo, S., Nikodemusz, E., Gundel, K. and Nagy, Z., 1997. Relations of plasma concentrations of urea, glucose and total protein to milk levels of urea, lactose and protein of grazing ewes during lactation. Arch. Tierz., 40: 265.

Bhat, A.S., 1999. Effect of special feeding on the blood profile of cows and buffaloes. Indian Vet. J., 76:501.

Csapo, J.J.; Tcszthelyil, T.; Csapo K.Z.; Lengycl, A.; Andrassy, B.G. and Varga V.E. 1998. Composition of colostrum and milk of different breeds of ewes. Acta Agaria Kaposvariensis, 2:1.

Dawson, L. E. R., Carson, A. F. and Kilpatrick, D. J., 1999. The effect of digestible undegradable protein concentration of concentrates and protein source offered to ewes in late pregnancy on colostrum production and lamb performance. Anim. Food. Sci. Technol., 82: 21.

Duncan, D.B., 1955. Multiple ranges and multiple F test. Biometrics, 11:1.

El-Sherif, M. M. A. and Assad, F., 2001. Changes in some blood constituents of Barki ewes during pregnancy and lactation under semi-arid conditions. Small Rumin.Res., 40: 269.

Frandson, R.D. and Spurgeon, T.L., 1992. Anatomy and physiology of farm animals. $5^{\text {th }}$ Ed. Lea and Febiger, Philadelphia, USA. p. 232.

Hafez, Y. M. and Maareck, Y. A., 2002. Variations in colostrum constituents and blood characteristics of Rahmani ewes in relation to dietary protein and days relative to parturition. Egypian J. Anim. Prod., 39: 125.

Hatfield, P.G.; Hopkins, J.A.; Ramsey, W.S and Gilmore, A. 1998. Effects of level of protein and type of molasses on digesta kinetics and blood metabolites in sheep. Small Rumin. Res. 28: 161.

Hill, P. A., Coghlan, J. P., Scoggins, B. A. and Ryan, G. B., 1984. Functional and morphological studies of the adrenal cortex and kidney in ovine toxaemia of pregnancy. J. Pathol., 144: 1.

Iriadam, M. ( 2007). Variation in certain hematological and biochemical parameters during the peri-partum period in Kilis does. Small Rumin. Res., 37: 54-57.

Jacobson, N.L. and McGilliard, A.D. 1984. The mammary gland and lactation. In: M. J. Swenson (Ed.), Duke's Physiology of Domestic Animals. Cornell Univ., Press, Ithaca, NY, USA. p. 863.

Lioyd, C. V., 1974. The ovaries. In: Williams, R. H. (Ed.), Text book of Endocrinology, W. B. Saunders Co., Philadelphia, USA. p. 459. 
MAFF. 1975. Ministry of Agriculture, Fisheries and Food. Energy allowances and feeding systems for ruminants. Tech. Bulletin.33. London HM60.

McDonald, P.; Edwards, R.A. and Greenhalgh, J.F.D., 1995. The energy value of milk. Animal Nutrition $5^{\text {th }}$ Ed., Longman, UK, p. 383.

McNeill, D. M., Slepetis, R., Ehrhardt, R. A. and Bell, A. W., 1997. Protein requirements of sheep in late pregnancy: partitioning of nitrogen between gravid uterus and maternal tissues. J. Anim. Sci., 75: 809.

Mellor, D.J. and Murray, L. 1985. Making the most of colostrum at lambing. Vet. Record, 118: 351.

NRC, 1986. National Research Council, $6^{\text {th }}$ Ed. Nutrient requirements of sheep. National Academy Press, Washington DC, USA.

Nowakowski, P.; Szule T.; Osman, K. and Kozyra, R. 1992. Variability in sheep colostrum composition. Zmiennosc Skladu Siary U Owiec, Zeszyty-NaukoweAkademii-Rolniczej-We-Eroclawiu-Zootechnika (Abstract)

Ocak, N. , Cam, M. A. and Kuran, M., 2005. The effect of high dietary protein levels during late gestation on colostrum yield and lamb survival rate in singletonbearing ewes. Small Rumin.Res.56: 89.

D'Oherty, A. and Crosby, T.F., 1997. The effect of diet in late pregnancy on colostrum production and immunoglobulin absorption in sheep. Animal Sci., 64:87.

Oyeniyi, O.O. and Hunter, A.G., 1978. Colostral constituents including immunoglobulin in the first three milkings postpartum. J. Dairy Sci. 61: 44.

Pakkanen, R. and Aalto, J., 1997. Growth factors and antimicrobial factors of bovine colostrum. Int. Dairy J., 7: 285.

Parveen, A. and Ahuja, S.P. 1999. Materno-neonatal transfer and intestinal absorption of immunoglobulins in buffaloes (Bubalus bubalis). Nut. Abst. and Rev. (Series B), Vol .69: abstract (2500).

Purohit, G.N.; V.K. Singh, B.L. Bishnol; I.S. Kohli and A.K. Gupta, 1999. Biochemical variations in blood profile of pregnant Bikaneri sheep. Indian J. Anim. Nutr. 16: 128.

Reece, W.O., 1991. Blood and its function, In: Physiology of Domestic Animals. Lea and Febiger, Philadelphia, USA. P. 91.

Regnault, T. R., Oddy, H. V., Nancarrow, C. and Scaramuzzi, R. J. (2004). Glucosestimulated insulin response in pregnant sheep following acute suppression of plasma non-estratified fatty acid concentrations. Reprod. Biol. Endocrinol. 2: 6469.

Rekwot, P.I.; Kumi-Diaka, J., Akerejola, O.O. and Oyedipe, E.O., 1999. Haematological values of Bunaji and Friesian x Bunaji bulls fed two levels of protein diets. Nut. Abst. Rev., Series B, Vol. 69.

Roeder, B.L., Thomas, V.M., Kott, R.W., Hatfield, P.G. and Burgress, D., 2000. Effect of short term preparatum feeding of level and type of protein on ewe performance and colostrum accumulation. Sheep and goat Res. J., 16:1.

SAS, 1998. SAS user's guide for personal computers, SAS Institute Inc., Cary, NC., USA.

Takarkheade, R. C., Gondane, V. C., Kolte, A. Y. and Rekhate, D. H., 1999. Biochemical profile during different phases of reproduction in ewes in comparison to rams. Indian Vet. J., $76: 205$. 
United States National Academy of Science. (1975). Nutrient requirements of domestic animals. No.5. Nutrient requirments of sheep. ( $5^{\text {th }}$ revised edition) (National Research Council, Washington, D. C.).

Zarkawi, M. and Soukouti, A., 2005. Serum progesterone levels using radioimmunoassay during oestrous cycle of indigenous Damascus does. New Zealand J.of Agric.Res.44: 165-169. 


\title{
تأثير نظم التغذية على الأداء التتاسلى والفسيولوجى والإتتاجى للماعز الشـامى فى المراحل الفسيولوجية المختلفة
}

\author{
محمد طارق عبد الفتاح بدوىـ كمال محمود يوسف
}

شعبة الاتتاج الصيوانس والدو/جن- مركز بحوث الصحراء

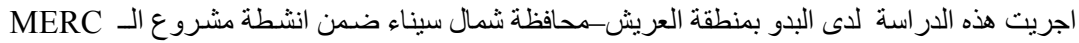

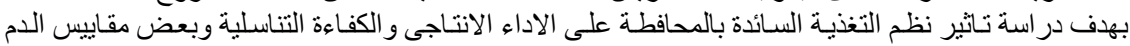

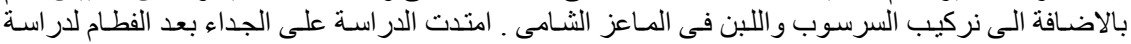
معدلات النمو وكذللك مو اصفات الذبيحة.

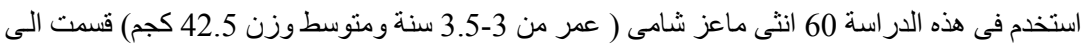

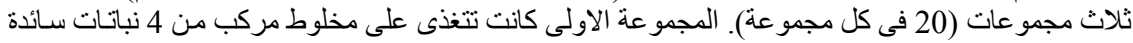

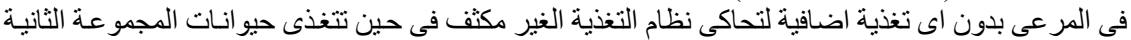

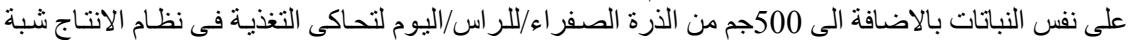

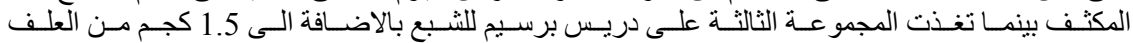

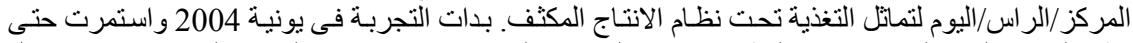

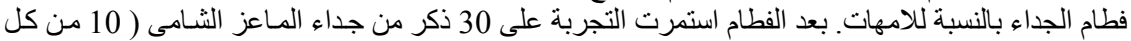

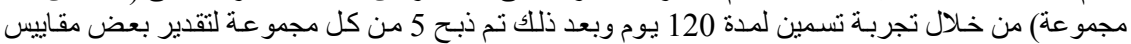

اوضحت النتائج ان نظام التغذية كان لة ناثثر ا معنويا على الماكول من البروتين الخـام و الطاقة الكلية حيث

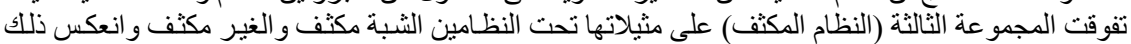
على محصول اللبن ومكوناتة وكذلك معدلات النمو ومو الصفات الذئات الذبيحة للجداء.

بلغ متوسط الماكول من المادة الجافة 1400 ، 1450.3 ، 1920 ، 2375 جم/للاسراس/اليوم وبلغ متوسط محصول

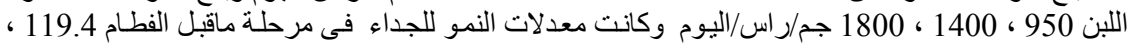

$$
180 \text { ، } 198.9 \text { جم/اليوم اللمجامبع الثلاثة على التو الى } 1800 \text { ، } 190
$$

أظهرت النتائج ان التغذية الاضافية (المجموعة الثانية) ادت الى تحسن معنوى في معلى معدلات الحمل و الو لادة

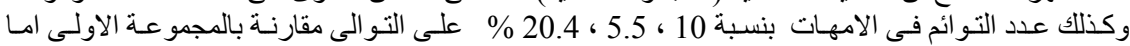

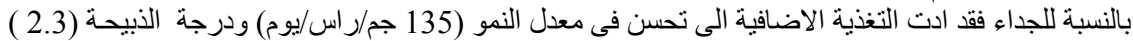
وكذلك نسبة التصافى (50 \%) مقارنة بالمجمو عة الاولى (97.5 ، 1.4 ، 137.2 \% على التى التو الى).

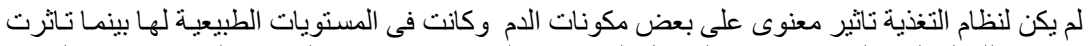

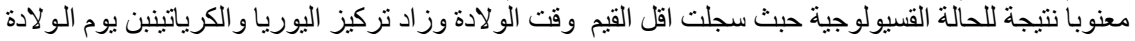
ثم ثبت بعد ذللك ولم يكن لانزيمات الكبد (AST \& ALT) اتجاة منتظم.

توصى الدر اسة بضرورة الاهتمام بالتغذية الاضافية للحيو انات فى المر احل الفسيولوجية الحرجة الحئ (الحمل-

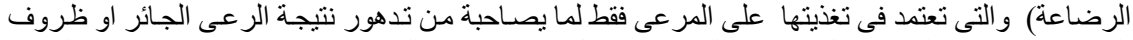

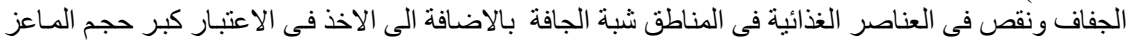


الثامى مقارنة بالماعز البلدى و انعكاس ذلك على احتباجاتة الغذائية الامر الذى قد يحد من انتشساره تحت نظسام الانتاج غير المكثف. 